\title{
The Adoption of WhatsApp: Breaking the Vicious Cycle of Technological Poverty in South Africa
}

\author{
Richard Shambare \\ Tshwane University of Technology, South Africa \\ shambarer@tut.ac.za
}

\begin{abstract}
Although research clearly demonstrates that consistent technology usage is correlated to socioeconomic development, the Vicious Cycle of Technology Affordability and Non-adoption impedes the uptake of ICTs in many developing countries. In South Africa, however, one Smartphone messaging application, WhatsApp, appears to have broken this vicious cycle. This paper argues that, given that promoting the uptake of ICTs is a developmental imperative for emerging economies, studying the adoption and diffusion patterns of WhatsApp provides invaluable insights into ICT usage within the context of a developing country. This study modelled the factors influencing the adoption of WhatsApp among South African youths. Some 192 students participated in the study by means of a self-completion questionnaire developed from the Technology Acceptance Model. Structural equation modelling tested the proposed theoretical model. Results suggest that a combination of cost efficiency, simplicity, userfriendly features, and the ability to run on multiple platforms influences and promotes users' attitudes and behavioural intentions to adopt WhatsApp.
\end{abstract}

Keywords: Adoption, SEM, South Africa, Smartphone's, TAM, technology leapfrogging, V-CAN, WhatsApp

\section{Introduction}

Development literature recognises the utility of technology in reversing marginalisation and promoting socio-economic development in Africa, in particular information and communication technologies (ICTs), which include the Internet, smart phones, and computers (Fong, 2009; Ndung'u, Waema\& Mitullah, 2012; Stork, Calandro\& Gillwald, 2013). Promoting the uptake of information and communication technologies (ICTs) is therefore a developmental imperative for emerging economies, including that of South Africa (Edoho, 2013). The literature cited clearly demonstrates that consistent use of ICTs is linked to socioeconomic development. These innovations have been successfully used in the promotion of education in South Africa (Shambare \& Mvula, 2011), poverty alleviation and micro-finance programmes in India (Donner \& Tellez, 2008), and small businesses in Kenya (Ndung'u et al., 2012).

The Affordability-Non Adoption Cycle: Two critical challenges related to ICT usage in Africa, and which currently create a vicious cycle of non-adoption, are access and affordability (Stork et al., 2013) and the challenges of attracting a critical mass of users. This study focuses in particular on, and aptly refers to, this phenomenon as the Vicious Cycle of Technology Affordability-Non Adoption (V-CAN) (see Figure 1). This 'vicious cycle' starts with the high cost of technology and the widespread existence of technology poverty on the continent, which means that many in Africa cannot afford ICTs. As a result of this low demand, the costs of marketing technologies for businesses remain exorbitant, and because of this high cost, lack of affordability leads to reduced access, which in turn creates technologically poor consumers. Figure 1 illustrates this cycle. The V-CAN model presupposes five elements leading to the non-adoption of technological innovations:

- Technology is too expensive: for many individuals in developing countries, technology is a 'luxury'. Because a significant proportion of the population in developing countries lives under $\$ 2$ a day, much of their income is directed towards food, shelter, clothing, and other basic necessities.

- Low Demand: as a result of the limited financial resources of a large proportion of consumers in developing countries, demand for technology-related products and services is greatly reduced.

- High business costs: since technology businesses are unable to sell large quantities, in the longrun their fixed costs (e.g. infrastructure) remain relatively high. Thus, average unit costs continue to escalate because of the diseconomies of scale. 
- $\quad$ Reduced technology access: poor technology infrastructure and connectivity challenges in developing countries because bottle necks in consumers' access to technology. In order to cover the escalating costs, technology businesses increase their mark up. Inevitably, retail prices go up, making technology ever more expensive and unreachable for these consumers.

- $\quad$ Technologically poor consumers: as a result of the above four factors, consumers in developing countries find it increasingly difficult to access technology. Declining real wages and increasing technology prices result in technologically 'poor' consumers - individuals with little or no access to technology.

Figure 1: The Vicious Cycle of Technology Affordability-Non Adoption

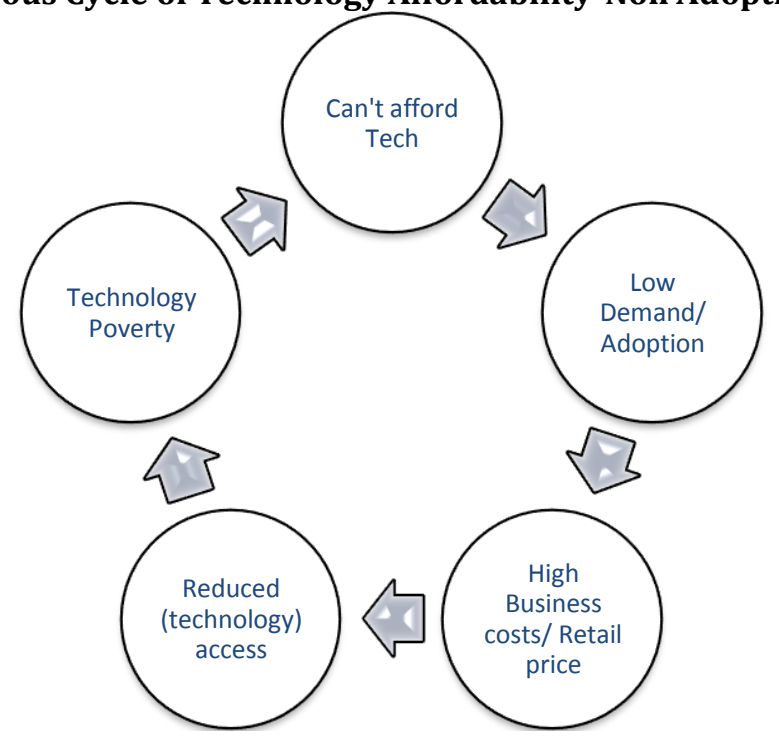

Many authors propose technology leapfrogging as a way of minimising the effects of the V-CAN (Fong, 2009; Nilsen, 2010; Schilling, 2003). Technology leapfrogging is defined as the introduction of technological innovations where no immediate prior technologies existed (Fong, 2009:3707).For this reason, the South African government, through the Green Paper on ICT Policy, views that with increase in access to "Smartphone technology, internet access will increase and with it access to information that can inspire and grow potential and knowledge across all ages" (Department of Communications, 2014:84). Therefore, in the South African context, technological leapfrogging refers to accelerating the adoption of mobile technologies by providing legal framework and infrastructural support for reduced tariffs and software development (Department of Communications, 2014).

Rationale and Purpose: From a technology acceptance perspective, WhatsApp's adoption record in developing countries potentially presents numerous lessons for addressing the technological poverty crisis. This is particularly true in those developing countries, such as South Africa, which are grappling with the question of technology leapfrogging (Fong, 2009). Clearly, the rapid adoption rates in South Africa, such as those witnessed in the diffusion of WhatsApp, constitute positive steps towards the contribution of the technology leapfrogging agenda (Fong, 2009). The purpose of this research is to investigate the factors influencing the adoption of WhatsApp among young adults in a developing country as well as establishing the usage patterns of the popular Smartphone application on the part of this age group. The remaining sections of this paper are arranged as follows: the features and usage of WhatsApp Messenger are described in the next section, followed by a discussion of the applicable adoption framework. This discussion is followed by an explanation of the methodological approaches used in this study, a presentation of the results, and a discussion of the findings. Finally, conclusions from these findings and the implications for theory and practice in the process of effective adoption of WhatsApp are discussed within the context of existing literature. 


\section{Literature Review}

WhatsApp Messenger: WhatsApp Messenger is a 'cross-platform messaging app which allows users to exchange messages without having to pay for SMS' (WhatsApp.com, 2012). The application is compatible with iPhone, BlackBerry, Android, Nokia, and other Windows smart phones. WhatsApp features include one-on-one chat, group chat, push notifications, sending and receiving both video and audio files. By April 2014 it was estimated that WhatsApp had approximately 500 million users (Statista, 2014), who send and receive more than 64 billion messages a day (Trenholm, 2014).

WhatsApp: Breaking the Affordability-Non Adoption Cycle: WhatsApp has tipped the Smartphone into mainstream culture. The Smartphone has revolutionised life on a global scale, including in developing countries (Donner \& Tellez, 2008; Shambare, Rugimbana \& Zhowa, 2012). In South Africa, for example, although numerous social apps (e.g., Facebook, Twitter, and Mixit) have been introduced, very few have been as widely-received as WhatsApp, which today is used by 15 million subscribers; compared to Facebook with 9 million and Mixit with 7 million subscribers (TruTower.com, 2014). According to a compilation of Google search statistics originating from South Africa for 2011, WhatsApp.com was observed to be the most 'googled' and downloaded site in that country (The Star, 2011). The fact that WhatsApp was introduced into the market in 2009, and has reached half a billion active users in less than five years, represents a remarkable accomplishment by any measure, and would suggest that this rapid diffusion and widespread adoption is worth exploring For the purposes of this research.

WhatsApp Adoption Conceptual Framework: The technology acceptance model (TAM) has been and is a widely used conceptual frame to explain the adoption processes of computer-related innovations (Alrafi, 1989; Chen, 2008; Davis, 1989; Masrom, 2007; Walczuch, Lemmink\& Streukens, 2007). I therefore selected TAM as the most appropriate conceptual frame for studying the adoption of WhatsApp. TAM presupposes two determinant variables to be associated with an innovation and its adoption: perceived usefulness (PU) and perceived ease of use (PEU) are drivers of its adoption by consumers (see Figure 2) (Alrafi, 1989; Davis, 1989).

\section{Figure 2: Conceptual model}

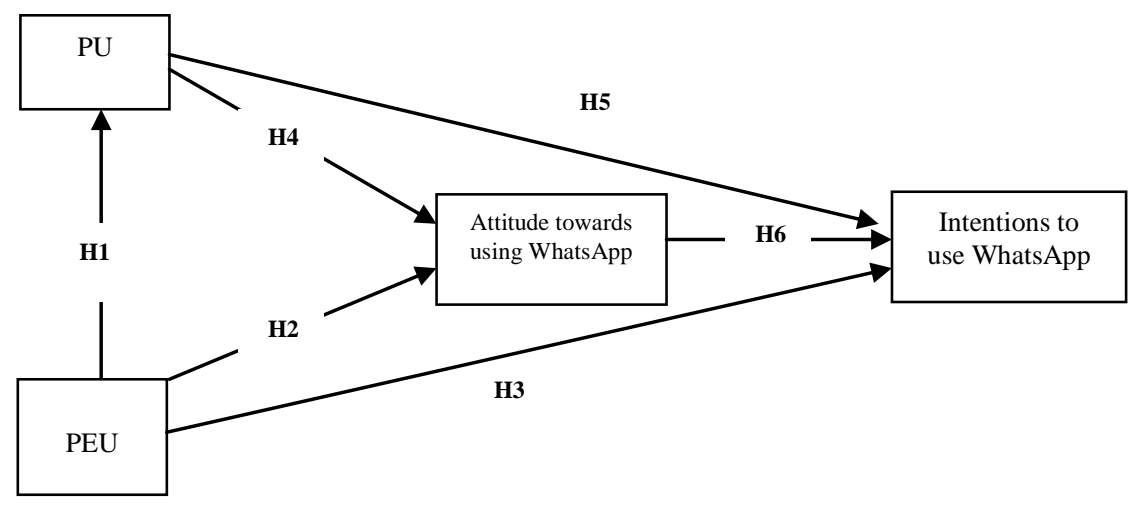

PEU, in the context of WhatsApp, refers to mobile subscribers' perceptions of the relative ease and lack of effort required to use the messaging application. PEU is closely related to Rogers' (1995) concept of 'complexity' which he defines as 'the degree to which an innovation is perceived as relatively difficult to understand and to use', seeing the 'perceived complexity of an innovation as negatively related to its rate of adoption' (Rogers, 1995: 242-243). PU, on the other hand, reflects cell phone users' subjective assessment of the extent to which WhatsApp will improve their lives; in other words, their perceptions of the utility or benefits derived from using WhatsApp (Alrafi, 1989; Tanakinjal, 2006). As Figure 2 illustrates, PU mediates the relationship between PEU and the attitudes of cell phone users as well as their behavioural intentions towards the adoption of innovations (Ma \& Liu, 2004). In simple terms, regardless of how beneficial a technology might be, if it is subject to limited accessibility and is difficult to use, its utility will be eroded. In this context the following (interrelated) hypotheses were formulated in terms of cell phone user's perceptions and attitudes (see Figure 2):

$\boldsymbol{H}_{1}$ : $\quad$ Perceived ease of use of WhatsApp has a significant effect on its perceived usefulness.

$\boldsymbol{H}_{2}$ : Perceived ease of use of WhatsApp has a significant effect on attitudes towards using WhatsApp. 
$\boldsymbol{H}_{3}: \quad$ Perceived ease of use of WhatsApp has a significant effect on the intention of cell phone users to use it.

$\boldsymbol{H}_{4}$ : $\quad$ Perceived usefulness has a significant effect on attitude towards using WhatsApp.

$\boldsymbol{H}_{5}: \quad$ Perceived usefulness of WhatsApp has a significant effect on the intention to use it.

$\boldsymbol{H}_{6}$ : $\quad$ Attitude towards using WhatsApp has a significant effect on the intention to use it.

\section{Methodology}

A descriptive research design, utilising a survey method (Malhotra, 2010), was used to collect primary data from university students at a South African metropolitan university in Pretoria. After being trained as research assistants, three undergraduate students helped with collecting primary data by administering the data collection instrument.

Data collection: The three research assistants were positioned at strategic locations around the university campus. These locations included high traffic areas on the university campus such as dining halls, restaurants, libraries, and sports arenas. I chose to collect data at these high (student) density areas because it increased the researchers' chances of drawing on a representative sample of students. In this way, a variant of the mall-intercept technique was applied in this study (Malhotra, 2010:215). This included erecting temporary data collection points, comprising chairs and desks manned by the research assistants. The research assistants solicited volunteers to participate in the study by inviting them to the makeshift research stations, where these participants sat and completed the self-administered questionnaires. In order to improve the response rate, the research assistants encouraged participants to complete the questionnaires, and, upon completion, to submit them on the spot. Research assistants then checked and sorted all questionnaires for completeness. Spoilt questionnaires, and those with more than four missing values in the TAM scale, were dropped from the study. Questionnaires with up to four missing values were accepted, as the missing values were addressed using expectation maximisation techniques to yield a complete data set with no missing values (Field, 2009).

Sample: Given that all the respondents were university students, homogenous sample (Monette, Sullivan\& DeJong, 2008) and non-probabilistic sampling techniques were considered appropriate (Calder, Phillips\& Tybout, 1981). In line with the convenience sampling method, some 350 questionnaires were distributed. Of these, 243 were returned, and of these, only 192 questionnaires were fully-completed and usable for further analysis. This represented a 55 per cent response rate. Table 1 shows the participants' demographic characteristics.

Table 1: Demographic Profile

\begin{tabular}{lll}
\hline Demographic Characteristics & Per cent (\%) \\
\hline Gender & Male & 38 \\
& Female & 62 \\
Education level & & \\
& $1^{\text {st }}$ year & 17 \\
& $2^{\text {nd }}$ year & 11 \\
& $3^{\text {rd year }}$ & 61 \\
& $4^{\text {th } \text { year }}$ & 8 \\
& Postgraduate & 3 \\
Use WhatsApp & & 70 \\
& Yes & 30 \\
WhatsApp awareness & No & 32 \\
& & \\
& $6-12$ months & 32 \\
& $>12$ months & 36 \\
\hline
\end{tabular}

A majority (70 per cent) of the respondents indicated that they used WhatsApp. In addition, more female participants (62 per cent) than male (38 per cent) took part in the study. Consistent with a student sample at most South African universities, respondents' ages ranged from 18 to 30 years, with a mean age of 21.20 years, and a standard deviation of 1.83 years. 
Data analysis: Statistical analyses were performed using SPSS 19 and AMOS 20 (Blumberg, Cooper\& Schindler, 2011; Field, 2009). The analysis performed ranged from basic descriptive analysis to chisquare tests, to structural equation modelling (SEM), which was utilised to test the hypothesised model.

\section{Results and Discussion}

Awareness and Use of WhatsApp: Invariably, awareness is an important prerequisite for any adoptionrejection decision. Rogers (1995) clearly demonstrates that, for any innovation, awareness is the most important first phase in the adoption life-cycle of the innovation. Simply and self-evidently put, an individual cannot possibly use and later adopt a product of which she or he is unaware. Even in Davies' (1989) TAM, this prerequisite is an important assumption and basis of the model. I would argue that it was thus insightful for of me to take into consideration the respondents' level of awareness of WhatsApp. Approximately 68 per cent of the respondents indicated at the time of data collection that they had been familiar with the product for at least six months. Some 70 per cent of respondents reported using WhatsApp on a daily basis (see Table 1). I defined using WhatsApp as either sending or receiving an instant message or a file over the WhatsApp platform. On the whole these results are not surprising, and furthermore, would seem to confirm the popularity of the Smartphone application (WhatsApp, 2014). To further qualify and expand on the notion of popularity in the study, it was instructive to establish the amount of time each participant spent using WhatsApp on a daily basis. Results show that only one-third (33 per cent) spent less than one hour a day on WhatsApp. The remaining 67 per cent found WhatsApp to be useful and spent more than one hour per day on it. Of these, 47 per cent were on WhatsApp for more than three hours per day. Figure 3 below depicts WhatsApp usage as being highest at the extremes in the form of a U-shaped graph, suggesting that subscribers either spend very little time or a considerable portion of their day sending and receiving messages via WhatsApp. It is almost important to note that there is almost no middle ground or moderate usage of WhatsApp.

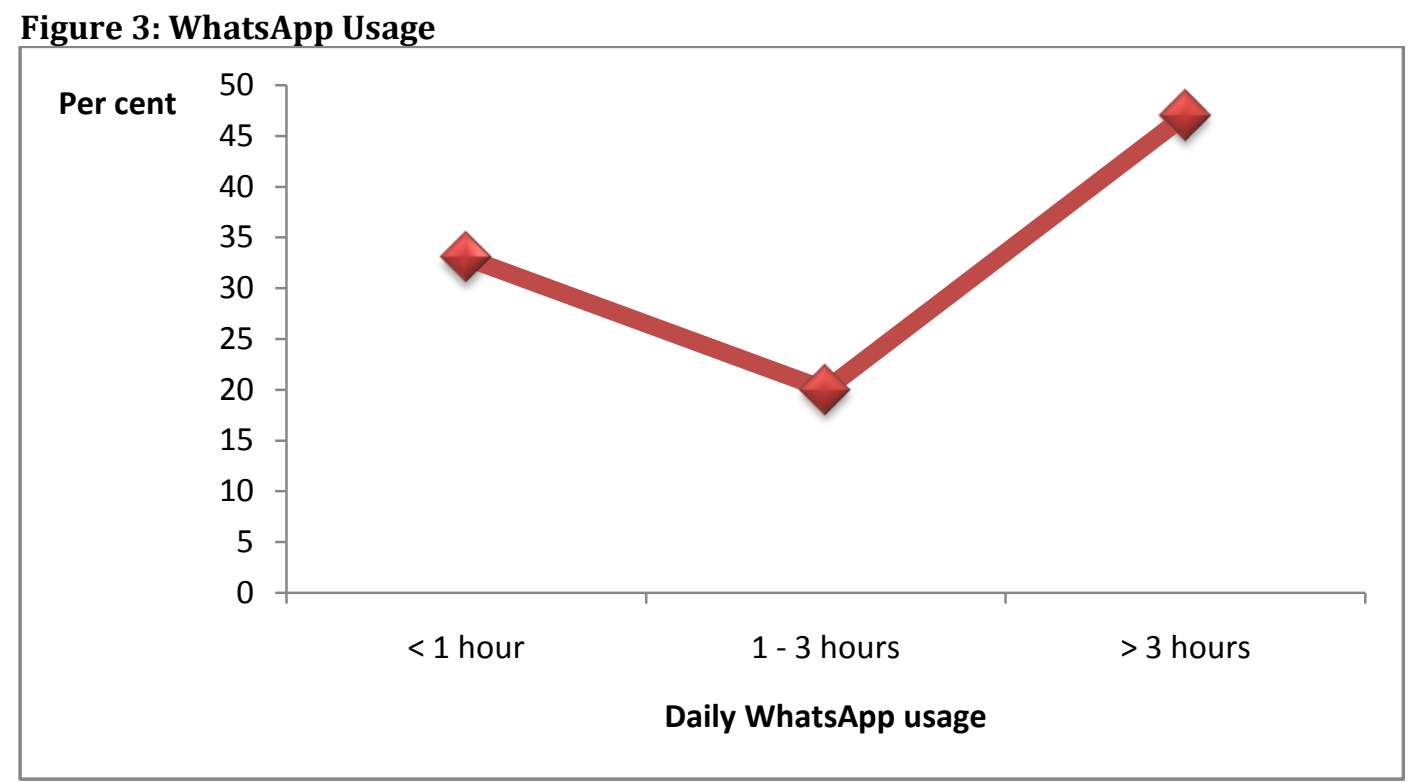

The fact that almost half ( 47 per cent) of the respondents use WhatsApp for at least three hours a day would seem to affirm not only the popularity of the product amongst this sample, but also its usefulness to them, thus aligning with the findings of the meta-analysis of similar empirical studies conducted by Ma and Liu (2004). While it may be argued that this finding might not appear to be substantial or significant, when these three hours are considered as a proportion of an individual's 16 hour-daily productive time, a totally different picture emerges. It shows in fact that these young consumers spend at least one-fifth of their daily time on WhatsApp. Given that these are full-time students, this is a substantial amount of time. As shown in Figure 3, instant messaging and chat proved to be the most popular function. Almost half (47 per cent) of the sample are active users of the WhatsApp instant messaging function. Overall, these results corroborate earlier findings that the Smartphone instant messaging function is popular and is among the most-used features on mobile devices (Hodenfield, 2013; Shambare et al., 2012). Shambare et al. (2012) in particular observe this phenomenon and comment that respondents in their study overwhelmingly reported responses, such as, 'I often feel upset to think that I might be missing calls or 
message'. This trend was also observed by Hodenfield (2013) who found that some Smartphone users send as many as 109 text messages a day and check for messages on their devices on average 60 times a day. Thus, the South African sample of Smartphone subscribers' usage patterns in terms of instant (text) messaging followed similar patterns to others in similar cohorts internationally.

Figure 4: WhatsApp Functions

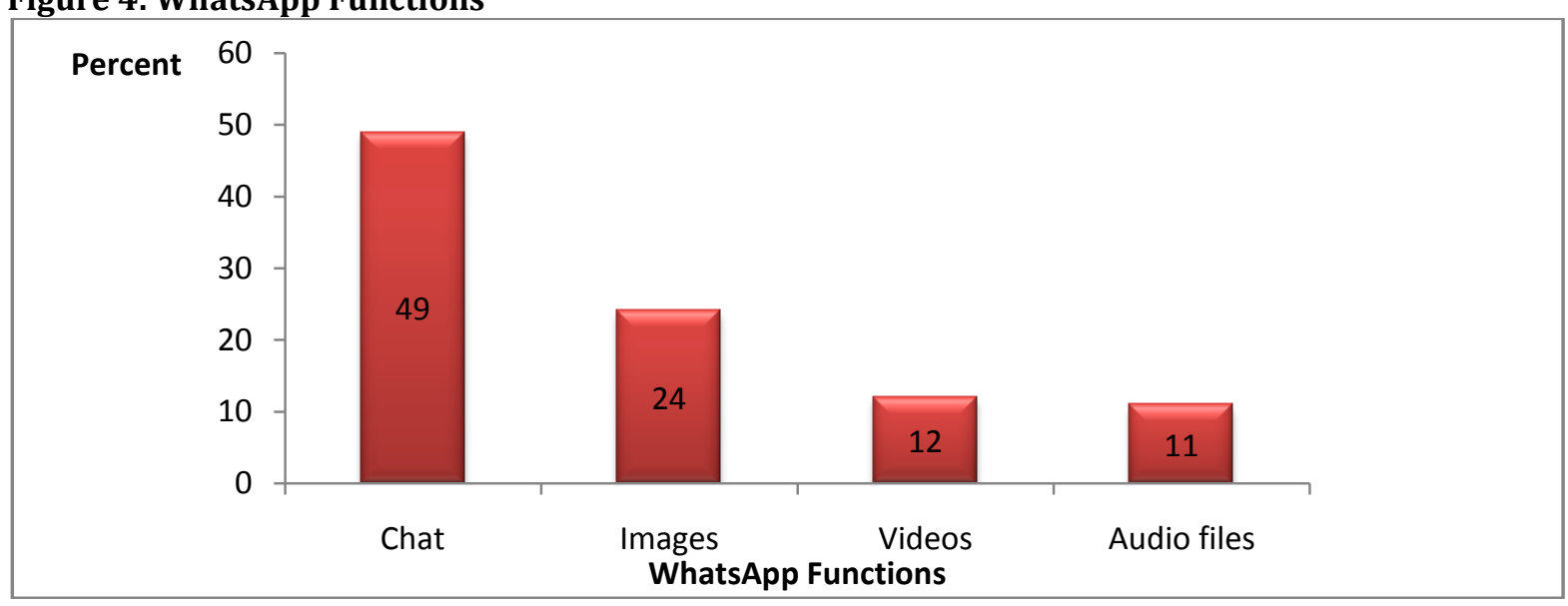

A notable observation since the introduction of WhatsApp is the decline in usage rates of other text-based messaging services, such as instant messaging, Blackberry messaging (BBM), and short message service (SMS) (Bradshaw, 2011). In the case of SMS services in particular, there are two clear advantages of WhatsApp. Firstly, the service is free. Secondly, subscribers can send an unlimited number of instant messages of unlimited size. Whereas in the case of ordinary SMSs, subscribers are billed in 160-character intervals, and thus a 161-character SMS is billed as two SMSs, WhatsApp subscribers do not experience such restrictions (WhatsApp.com, 2012). Thus to many consumers, particularly students, WhatsApp has a multiplicity of relative advantages over SMSs. Compared to BBM, although supporting similar functionalities, WhatsApp still proves to be significantly more advantageous to consumers (Bradshaw, 2011). To access BBM services, Blackberry subscribers pay a R59 (US $\$ 5.50^{1}$ ) monthly fee, which is not the case with WhatsApp, whose annual subscription is only US $\$ 0.99$ (WhatsApp.com, 2012).

WhatsApp Adoption: In this study several hypotheses related to the adoption of WhatsApp were formulated in line with TAM (Figure 2). The 15-item TAM scale was used to determine which factors influenced the adoption of WhatsApp. The construct validity of the questionnaire was tested and confirmed by means of confirmatory factor analysis (Pallant, 2010). Thereafter the fit of the proposed conceptual model, as illustrated in Figure 2, was tested using structural equation modelling (SEM) utilising the path analysis technique (Malhotra, 2010). The structure illustrated in Figure 5 yielded the best model fit. The model was assessed by the chi-square $\left(X^{2}=.803 ; \mathrm{df}=2 ; \mathrm{p}=.669\right)$, which indicated a good model fit with acceptable fit statistics (Jackson, Dezee, Douglas\& Shimeall, 2005).

\section{Figure 5: WhatsApp structural model}

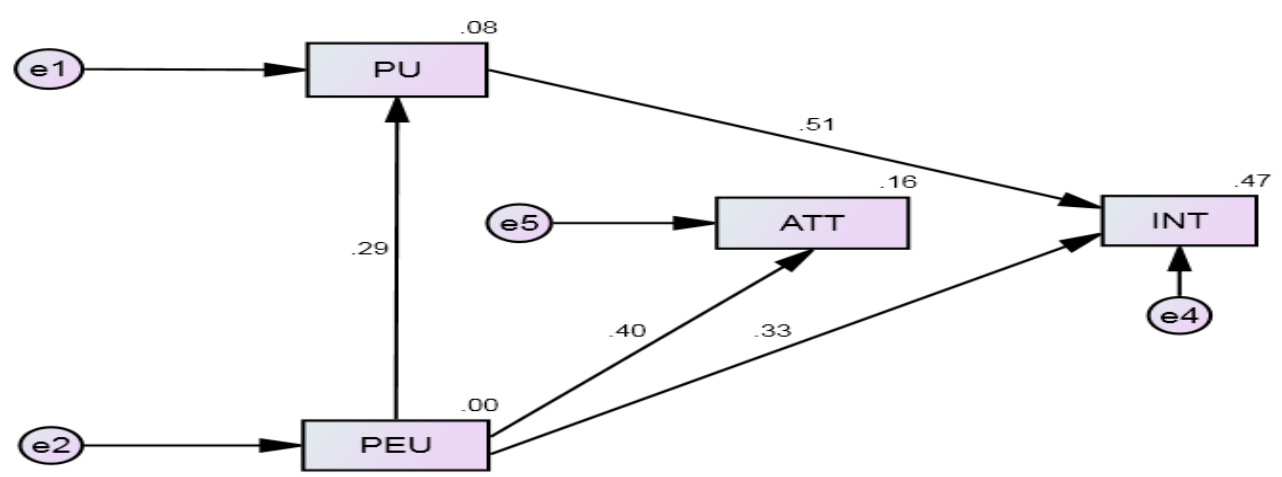

${ }^{1}$ The USD-ZAR exchange rate as at 10 July 2014 
The Normed Fit Index (NFI) yielded a score of .995, with a comparative fit index (CFI) of approximately 1.000. The close fit of the model, as measured by the Root Mean Square of Error of Approximation (RMSEA), yielded a statistic equal to .000 , with the PCLOSE $p$-value $=.776$, suggesting that the model was satisfactory (Barrett, 2007).

Figure 5 indicates that the sample data found support for four of the six tested hypotheses. The significant hypotheses were:

$\boldsymbol{H}_{1}$ : $\quad$ Perceived ease of use of WhatsApp has a significant effect on its perceived usefulness.

$\boldsymbol{H}_{2}$ : $\quad$ Perceived ease of use of WhatsApp has a significant effect on attitude towards using WhatsApp.

$\boldsymbol{H}_{3}: \quad$ Perceived ease of use of WhatsApp has a significant effect on the intention towards using it.

$\boldsymbol{H}_{5}: \quad$ Perceived usefulness of WhatsApp has a significant effect on the intention to use it.

Thus, while perceived ease of use was found in this and other studies to promote a positive attitude towards adopting the product, the effect of attitude on intention was not statistically significant ( $p>.05$ ). Interestingly, perceived usefulness was also found not to have an effect on participants' attitude towards using WhatsApp. If one looks closely at Figure 5, it becomes clear that, while both PEU and PU are important in influencing usage and acceptance of WhatsApp, statistically, PU is shown to have a greater influence on intentions, as shown by a higher coefficient (.51 compared to .33 for PEU). This suggests that the perceptions of participants of its utility, or their feelings that the product will benefit the adopter, far outweigh its 'perceived complexity' (Rogers, 1995) as far as adoption is concerned (Masrom, 2007).

\section{Conclusion}

The purpose of this research was to investigate the factors influencing the adoption of WhatsApp in a developing country, specifically amongst young South Africans, and to establish WhatsApp's usage patterns in this group. Of particular interest and value was identifying lessons from WhatsApp's rapid diffusion. As previously indicated, TAM was used in the study to model the adoption patterns of this messaging service by the participants. Results found support for four of the six tested hypotheses - H1, $\mathrm{H} 2, \mathrm{H} 3$, and H5. Overall, these findings conform to the results observed in past studies. Of note is the fact that perceived ease of use greatly influences perceived usefulness of WhatsApp (or any other innovation, for that matter). The implication is that, if a technology is difficult to use, or perceived to be so, then its usefulness to the adopter becomes greatly diminished. Although perceived ease of use is an important construct, comparatively perceived usefulness has a greater influence on consumers' intentions to use an innovation. This suggests that, even if an innovation is very simple to use, if it fails to address a tangible need on the part of users, then its chances of adoption will be compromised, as it serves, or is perceived to serve, no purpose for the consumers. The results of this study therefore reinforce previous findings which suggest perceived attributes of innovations are important in predicting their acceptance and usage (Masrom, 2007; Yi, Tung\& Wu, 2003).

It was interesting to note that there was an observed decline in the use of other services such as SMS and BBM. This seems to suggest the strategic importance of the relative advantages of certain innovations in comparison to others. Thus, when designing new products or improving on existing ones, marketers should ensure that they incorporate features that clearly separate their products from those of competitors in terms of usefulness. Without these features, diffusion of these products is likely to be slow, particularly since the switching costs tend to be high (Meuter, Bitner \& Brown, 2005). Furthermore, particularly with WhatsApp, the results suggest that a combination of cost efficiency, simplicity, userfriendly features, and the ability to run on multiple platforms promotes users' attitudes and behavioural intentions to adopting WhatsApp. These features were also observed in this study as having the ability to break the Vicious Cycle of Technology Affordability-Non Adoption. Given the economic situation (i.e. widespread poverty) in many Third World countries, economic decisions relating to products (including ICTs) come to constitute one of the most important adoption-rejection criteria. In terms of WhatsApp, the service is very affordable: it is free to download and, once downloaded, users pay a mere $\$ 0.99$ subscription per year. Also, WhatsApp's ability to work on different mobile phones and platforms means that users need not purchase certain devices to access the programme. Since mobile and Smartphone penetration in South Africa is already high (Shambare et al., 2012), a large section of the South African population are well prepared and primed for WhatsApp adoption. The fact that sending and receiving messages via WhatsApp is free makes the service extremely popular. In short, WhatsApp is a practical 
communication tool that addresses consumers' need to communicate effectively and cheaply - through text, video and audio.

Overall, the findings of this study suggest that WhatsApp is a very popular instant messaging service. More importantly, the findings confirm other studies that show that it has been widely accepted by young South African consumers, especially by students. Its widespread uptake, given that the innovation is still fairly new in the South African marketplace, provides strong evidence that a good product design that meets and satisfies customer needs, and is reasonably priced, will always diffuse rapidly in society, not only through advertising, but also through word-of-mouth. Particularly, the latter has been witnessed in products such as Skype, Google, Facebook, Twitter, and even BBM among university students. It is in this context that future researchers could consider studying the applicability of WhatsApp and similar technologies in education in developing countries, especially those with poor education infrastructure. In this context, it would be particularly interesting to determine the level of readiness of learners as well as their instructors to receive and to use the technology in a teaching environment. Research involving a different consumer segment might also provide useful insights into the usage and adoption patterns of this new technology. Further testing and validation of the V-CAN model can provide valuable knowledge in terms of the adoption of ICTs in developing countries.

\section{References}

Alrafi, A. (1989). Technology Acceptance Model. Engineering, 22, 1-12.

Barrett, P. (2007). Structural equation modelling: Adjudging model fit. Personality and Individual Differences, 42, 815-824.

Blumberg, B., Cooper, D. R. \& Schindler, P. S. (2011). Business Research Methods (3rded.). London: McGraw Hill.

Bradshaw, T. (2011). WhatsApp users get the message[Online]. Retrieved April 20 2012: http://www.ft.com/intl/cms/s/2/30fd99a2-0c60-11e1-88c600144feabdc0.html\#axzz1snbRCmxB

Calder, B. J., Phillips, L. W. \& Tybout, A. M. (1981). Designing Research for Application. The Journal of Consumer Research, 8(2), 197-207.

Chen, L. (2008). A model of consumer acceptance of mobile payment. International Journal of Mobile Communications, 6(1), 32-52.

Davis, D. (1989). Perceived Usefulness, Perceived Ease of Use, and User Acceptance of Information Technology. MIS Quarterly, 13(3), 319-340.

Department of Communications. (2014). National Integrated ICT Policy Green Paper. Government Gazette, $44,37261$.

Donner, J. \& Tellez, C. (2008). Mobile banking and economic development: linking adoption, impact, and use. Asian Journal of Communication, 18(4), 318-322.

Edoho, F. M. (2013). Information and communications technologies in the age of globalization. African Journal of Economic and Management Sciences, 4(1), 9-33.

Field, A. (2009). Discovering Statistics Using SPSS (3rd ed.). Thousand Oaks, CA: Sage.

Fong, M. W. L. (2009). Technology Leapfrogging for Developing Countries. Global Information Technology, 5, 3707-3713.

Hodenfield, H. H. (2013). Smartphones: The 21st Century Narcotic[Online]. Retrieved July 22014 : http://www.thefix.com/content/nomophobia-cell-phone-addiction-brain-cancer2004?page=all

Jackson, J. L., Dezee, K., Douglas, K. \& Shimeall, W. (2005). Introduction to Structural Equation Modeling (Path Analysis): Society of General Internal Medicine (SGIM) Precourse Handout [Online]. Retrieved:http://www.sgim.org/userfiles/file/AMHandouts/AM05/handouts/PA08.pdf.

Ma, Q. \& Liu, L. (2004). The Technology Acceptance Model: A Meta-Analysis of Empirical Findings. Journal of End User Computing, 16(1), 59-72.

Malhotra, N. (2010). Marketing Research: An Applied Orientation (6th ed.). Upper Saddle River, NJ: Pearson.

Masrom, M. (2007). Technology Acceptance and E-Learning. Unpublished paper presented at the 12th International Conference on Education, Sultan Hassanal Bolkiah Institute of Education, 21-24 May.

Meuter, M. L., Bitner, M. J. A. L, O. \& Brown, S. W. (2005). Choosing among alternative service delivery modes: an investigation of customer trial of self-service. Journal of Marketing, 69, 61-83.

Monette, D. R., Sullivan, T. J. \& DeJong, C. R. (2008). Applied Social Research: A tool for the Human Sciences (7th ed.). Belmont, CA: Cengage. 
Ndung'u, M. N., Waema, T. M. \& Mitullah, W. V. (2012). Factors influencing usage of new technologies in low-income households in Kenya: the case of Nairobi. info, 14(4), 52-64.

Nilsen, O. B. (2010). Learning-by-Doing or Technological Leapfrogging: Production Frontiers and Efficiency Measurement in Norwegian Salmon Aquaculture. Aquaculture Economics \& Management, 14(2), 97-119.

Pallant, J. (2010). SPSS Survival Manual: A step by step guide to data analysis using SPSS (4th ed.). Berkshire, UK: McGraw Hill.

Rogers, E. M. (1995). Diffusion of innovations (4th ed.). New York: Free Press.

Schilling, M. A. (2003). Technological Leapfrogging: Lessons from the U.S. Video Game Console Industry. California Management Review, 45(3), 6-32.

Shambare, R. \& Mvula, A. (2011). South African students' perceptions of Facebook: Some implications for instructors. African Journal of Business Management, 5(26), 10567-10564.

Shambare, R., Rugimbana, R. \& Zhowa, T. (2012). Are mobile phones the 21st century addiction? African Journal of Business Management, 6(2), 573-577.

Statista. (2014). Number of monthly active WhatsApp users worldwide from April 2013 to April 2014[Online].Retrieved: June 30 2014: http://www.statista.com/statistics/260819/number-ofmonthly-active-whatsapp-users/

Stork, C., Calandro, E. \& Gillwald, A. (2013). Internet going mobile: internet access and use in 11 African countries. info, 15(5), 34-51.

Tanakinjal, G. H. (2006). Short Message Service (SMS) and Banking. (PhD Marketing Colloquium), University of Otago, Otago, New Zealand. [Online] Retrieved: March 3 2013: http://eprints.otago.ac.nz/562/

The Star. (2011). How South Africa Googled in 2011. [Online]. Retrieved Jan. 232013 : http://www.iol.co.za/the-star/how-south-africa-googled-in-2011-1.1198832\#.U8L0RdKKCM8

Trenholm, R. (2014). WhatsApp zooms to record 64 billion messages in one day[Online]. Retrieved July 9 2014:http://www.cnet.com/news/whatsapp-zaps-record-64-billion-messages-in-one-day/

TruTower.com. (2014). Retrived: July 13 2014: http://www.trutower.com/2013/09/16/whatsappmessenger-ranking-in-south-africa/

Walczuch, R., Lemmink, J. \& Streukens, S. (2007). The effect of service employees' technology readiness on technology acceptance. Information \& Management, 44, 206-215.

WhatsApp.com. (2012). WhatsApp - How it works[Online]. Retrieved April 212012 : http://www.whatsapp.com

Yi, Y., Tung, L. L. \& Wu, Z. (2003). Incorporating technology readiness (TR), into TAM: are individual traits important to understand technology acceptance?Unpublished paper presented at the Diffusion Interest Group in Information Technology (DIGIT) Workshop, Seattle, WA. 